\title{
IMPLEMENTASI KEBIJAKAN SEKOLAH GRATIS DI SMP JUARA KOTA PEKANBARU
}

\author{
Rian Mahilda \\ Azhar \\ Daviq Chairilsyah \\ 1)Post Graduate Student of Riau University \\ ${ }^{2)}$ Lecturer of Education Management Study Programme PPs University of Riau \\ ${ }^{3)}$ Lecturer of Education Management Study Programme PPs University of Riau
}

\begin{abstract}
This study aimed to obtain information on the implementation of the policy of free school for underprivileged students in terms of economics in the Champions Junior High School Pekanbaru. Sub focus in this study were: (1) Understanding the implementation of free school policy in the Champions Junior High School Pekanbaru. (2) What were the Objectives, requirements and budget in the the implementation of free school policy are implemented. (3) The supporting factors of the implementation of free school policy in the Champions Junior High School Pekanbaru. (4) The obstacles that arise in the implementation of free school policy. (5) How to overcoming the obstacles to the implementation of free policy. This study used a qualitative approach. Data collection techniques in this research were through observation, interviews, documentation and triangulation. Data were analyzed by using analysis model Milles and Hubberman. Based on the results of this study concluded that: (1) The Implementation of free school policy in the Champions Junior High School is already match with the expectation (2) Input and output are in accordance with Implementation of free school policy in the Champions Junior High School is received underprivileged students in economics, the Champions Junior High School students have get many achievements both in academic and non-academic, and the Champions Junior High School graduates able to compete go to Senior high school, MA, and SMK both state and private. (3) Supporting factors are the Zakat house Foundations, Pekanbaru city government, the school, and the parents of student. (4) The obstacles that arise was delay disbursement of BOS funds, to convince the students and parents about the importance of education, there are still teachers who teach subjects other than their science subject, and still lack of facilities and infrastructure to support teaching and learning process. (5) Problems solving of the implementation of free school policy has been pursued its complete, although it is not maximized overall.
\end{abstract}

Key words: Implementation Policy, Free School.

ABSTRAK: Penelitian ini bertujuan untuk memperoleh informasi tentang pelaksanaan kebijakan sekolah gratis untuk siswa yang kurang mampu dari segi ekonomi di SMP Juara Pekanbaru. Sub fokus dalam penelitian ini adalah: (1) Memahami implementasi kebijakan sekolah gratis di SMP Juara Pekanbaru. (2) Sasaran, persyaratan dan anggaran dalam penerapan implementasi kebijakan sekolah gratis yang dilaksanakan. (3) Faktor-faktor pendukung implementasi kebijakan sekolah gratis di SMP Juara Pekanbaru. (4) Kendala-kendala yang muncul dalam implementasi kebijakan sekolah gratis. (5) Mengatasi kendala-kendala dalam implementasi kebijakan sekolah gratis. Penelitian ini menggunakan pendekatan kualitatif. Teknik pengumpulan data dalam penelitian ini melalui observasi, wawancara, dokumentasi dan triangulasi. Teknik analisis data menggunakan model analisis Milles dan Hubberman. Berdasarkan hasil penelitian dapat disimpulkan bahwa: (1) Implementasi kebijakan sekolah gratis SMP Juara Pekanbaru sudah 
berjalan atau dilaksanakan sesuai dengan yang diharapkan. (2) Input dan output telah sesuai dengan implementasi kebijakan sekolah gratis SMP Juara Pekanbaru yaitu yang diterima di SMP Juara Pekanbaru adalah siswa yang kurang mampu di bidang ekonomi, siswa SMP Juara banyak memperoleh prestasi baik akademik maupun non akademik, dan lulusan SMP Juara mampu bersaing masuk ke SMA, MA dan SMK baik Negeri maupun Swasta. (3) Faktor pendukung yaitu Yayasan Rumah Zakat, Pemerintah Kota Pekanbaru, pihak sekolah, dan wali murid. (4) Kendala-kendala yang muncul keterlambatan pencairan dana BOS, meyakinkan siswa dan orang tua tentang pentingnya pendidikan, masih adanya guru yang mengajar mata pelajaran yang lain selain ilmu terapannya, dan masih kurangnya sarana dan prasarana pendukung pembelajaran. (5) Masalah yang muncul dalam implementasi kebijakan sekolah gratis telah diupayakan penyelesaiannya, meskipun belum maksimal secara keseluruhan.

Kata Kunci: Implementasi Kebijakan, Sekolah Gratis.

\section{PENDAHULUAN}

Undang-Undang Dasar 1945 pasal 31 ayat (1) yang berbunyi, "Setiap warga negara berhak mendapat pendidikan”, dan pasal (2), “Setiap warga negara wajib mengikuti pendidikan dasar dan pemerintahan wajib membiayainya”. Ini adalah amanat yang harus dijalani oleh pemerintah, karena pendidikan adalah media mencerdaskan kehidupan bangsa dan akan membawa bangsa itu ke era pencerahan. Pendidikan bertujuan untuk membangun tatanan bangsa yang berbalut nilainilai kepintaran, kepekaan, dan kepedulian terhadap kehidupan berbangsa dan bernegara. Pendidikan merupakan tonggak kuat untuk mengentaskan kemiskinan pengetahuan, menyelesaikan persoalan kebodohan, dan menuntaskan permasalahan bangsa yang selama ini terjadi.

Fenomena yang ada seiring dengan perkembangan teknologi dan komunikasi tersebut, masalah pendidikan masih banyak hal yang perlu diselesaikan. Masalah-masalah tersebut diantaranya meliputi pemerataan pendidikan, relevansi pendidikan serta efektifitas dan efisiensi pendidikan yang akan bermuara pada masalah pendidikan. Masalah-masalah pendidikan tersebut hendaklah segera dipecahkan sebagai konsekuensi pemerintah dalam meningkatkan kualitas pendidikan dan keberhasilan dari tujuan pendidikan. Sejalan dengan semangat desentralisasi pemerintah, maka pengelolaan sekolah mengalami perubahan. Perubahan tersebut merupakan reformasi dalam manajemen sekolah. Sekolah diberikan kepercayaan untuk mengelola sendiri (selfmanagement).

Salah satu penyebab rendahnya partisipasi pendidikan dari masyarakat adalah tingginya biaya pendidikan, baik biaya langsung maupun tidak langsung. Biaya langsung seperti iuran sekolah, buku, seragam, alat tulis dan lain-lain. Sedangkan biaya tidak langsung seperti biaya transportasi, biaya kursus, uang saku dan biaya lain-lain. Undang-undang Nomor 20 Tahun 2003 pasal 11 ayat 2 tentang Sistem Pendidikan Nasional mengamanatkan "Pemerintah dan Pemerintah Daerah wajib menjamin tersedianya dana guna terselenggaranya pendidikan bagi setiap warga negara yang berusia tujuh sampai dengan lima belas tahun”. Konsekuensi dari amanat Undang-Undang tersebut, maka pemerintah wajib memberikan layanan pendidikan bagi seluruh peserta didik pada tingkat pendidikan dasar (SD/MI dan SMP/MTs serta satuan pendidikan yang sederajat).

Sejak tahun 2005, seluruh anak sekolah di Indonesia memperoleh dana Bantuan Operasional Sekolah (BOS) dari pemerintah pusat sebagai dampak dari pengurangan subsidi BBM pada tahun 2005 dan sehubungan dengan penuntasan wajar 9 tahun yang kemudian pemerintah memprogramkan pemberian kompensasi di bidang pendidikan yaitu BOS tersebut. Oleh karena itu, untuk anak-anak SD sudah bisa dikatakan langsung gratis karena dana dari BOS sudah mencukupi. Sehingga sejak 
tahun 2005 sudah tidak lagi ditarik iuran sekolah, baik SPP (Sumbangan Pembinaan Pendidikan) maupun BP3 (Badan Pembinaan Penyelenggaraan Pendidikan) yang dikelola oleh Komite Sekolah. Sekarang tinggal nasib anakanak SMP dan SMA. Ternyata walaupun sudah dikurangi oleh dana BOS, biaya untuk menggratiskan mereka hanya Rp 39.5 miliar. Itu dilihat dari indeks kebutuhan siswa dikalikan setahun untuk seluruh anak. Jadi, bagi peserta didik tingkat SMP dan SMA masih perlu adanya bantuan keuangan lagi di bidang pendidikan tersebut di samping dana BOS agar pendidikan mereka berjalan dengan lancar.

Dengan adanya fenomena tersebut, Rumah Zakat Indonesia (RZI) sebagai organisasi kemanusiaan yang membangun kemandirian dan pelayanan masyarakat, sejak awal berdirinya, Rumah Zakat telah fokus kepada program Pendidikan. Diawali dengan Kembalikan Senyum Anak Bangsa (KSAB), sebuah program pemberian beasiswa bagi siswa SD, SMP dan SMA di Indonesia.

Akan tetapi, pemberian beasiswa bukanlah tujuan akhir program EduCare RZI. Ada keinginan kuat dari RZI untuk menggulirkan program yang berkesinambungan dalam membina dan mencerdaskan anak bangsa yang terkendala dalam masalah ekonomi yaitu dengan menyelenggarakan program Sekolah Gratis Berkualitas. Sebuah program yang menyediakan infrastruktur, sarana dan prasarana pendidikan secara gratis kepada anak bangsa yang tidak mampu secara finansial.

Pada tahun 2008 mulailah didirikan Sekolah Juara oleh Yayasan Rumah Zakat yang pertama di Kota Bandung, selanjutnya terus didirikan di kota-kota lain. Sampai tahun 2010 ini telah berdiri sekolah juara di 10 Kota se-Indonesia (Bandung, Cimahi, Pekanbaru, Jakarta Pusat, Jakarta timur, Jakarta Selatan, Medan, Yogyakarta, Semarang dan Surabaya) dan mendapat respon positif dari masyarakat dan aparat pemerintah setempat. Sebagai bentuk kesinambungan program ini serta sejalan dengan program Wajar Dikdas 9 tahun, Rumah Juara Indonesia akan melanjutkan pengembangan sekolah ke level yang lebih tinggi, yaitu SMP Juara.

Dalam hal ini pemerintah Kota Pekanbaru yang bertindak sebagai pemerintah daerah setempat yang memiliki hak dan wewenang dalam pendidikan. Kebijakan yang diambil oleh pemerintahan Kota Pekanbaru melalui Dinas Pendidikan Kota Pekanbaru berdasarkan Nomor 420/Sekretaris.3/II/2013/2441 adalah dengan memberi izin daftar sekolah untuk sekolah SMP JUARA Pekanbaru dengan alamat sekolah Jl. Legasari Kel. Tangkerang Selatan Kec. Bukit Raya dan SK Pendirian 420/Bid.SM.1/2012/ 6951 Tanggal 20 September 2012 dengan NSS 20.4.09.60.02.110 dan NIS 201100.

\section{Fokus dan Subfokus Penelitian}

Sejalan dengan fenomena yang disebutkan di atas, maka yang menjadi fokus penelitian implementasi kebijakan sekolah gratis, adalah: Implementasi Kebijakan Sekolah Gratis di SMP Juara Pekanbaru.

Berdasarkan rumusan fokus penelitian di atas, maka yang merupakan sub fokus penelitian, sebagai berikut:

1. Memahami implementasi kebijakan sekolah gratis di SMP Juara Pekanbaru.

2. Sasaran, persyaratan dan anggaran dalam penerapan implementasi kebijakan sekolah gratis yang dilaksanakan.

3. Faktor-faktor pendukung implementasi kebijakan sekolah gratis di SMP Juara Kota Pekanbaru.

4. Kendala-kendala yang muncul dalam implementasi kebijakan sekolah gratis.

5. Mengatasi kendala-kendala dalam implementasi kebijakan sekolah gratis.

\section{Pertanyaan Penelitian}

Selaras dengan latar belakang masalah dan fokus penelitian yang tersebut di atas, maka pertanyaan penelitian mengenai permasalahan apa saja yang akan diteliti untuk mendapatkan jawabannya, dapat dikemukakan pertanyaan penelitian yang akan dikaji sebagai berikut: 
1. Bagaimana implementasi kebijakan sekolah gratis di SMP Juara Kota Pekanbaru?

2. Apa saja yang menjadi sasaran, persyaratan dan anggaran dalam penerapan implementasi kebijakan sekolah gratis yang dilaksanakan?

3. Apa saja faktor-faktor pendukung implementasi kebijakan sekolah gratis di SMP Juara Kota Pekanbaru?

4. Apa saja kendala-kendala yang muncul dalam penerapan implementasi kebijakan sekolah gratis?

5. Bagaimana mengatasi kendala-kendala dalam implementasi kebijakan sekolah gratis?

\section{METODE DAN PENELITIAN}

Penelitian ini merupakan penelitian lapangan artinya sebagian besar datanya diperoleh dengan cara mengumpulkan dari pengalaman empiris dilapangan atau kancah penelitian dengan pendekatan kualitatif. Pendekatan kualitarif dilaksanakan sebagai upaya memahami situasi tertentu dengan bentuk penelitian studi kasus.

1. Prosedur Penelitian

Prosedur penelitian ini dilakukan dengan tahapan:

i. Persiapan

1. Mengurus perizinan.

2. Observasi awal desain penelitian, merencanakan jadwal penelitian, dan menyusun instrumen penelitian.

ii. Pengumpulan data

1. Mengumpulkan data di lokasi dengan melaksanakan observasi, wawancara, dan analisis dokumen.

2. Membuat deskripsi dan refleksi data.

3. Menentukan strategi pengumpulan data yang lebih fokus.

4. Mereduksi data.

iii. Analisis data

1. Melakukan analisis awal.

2. Menyajikan data untuk keperluan analisis.

3. Melakukan analisis unit data untuk mengembangkan data selanjutnya.

4. Melakukan analisis antar unit untuk disatukan menjadi analisis akhir.

iv. Membuat kesimpulan

1. Melengkapi data jika ada yang belum lengkap.

2. Merumuskan implikasi kebijakan guna mengembangkan saran penelitian.

v. Pelaporan hasil penelitian

Data adalah keterangan atau bahan nyata yang dapat dijadikan bahan kajian (analisis atau kesimpulan). Ketepatan dalam memilih dan menentukan sumber data dalam penelitian akan turut menetukan ketepatan, kekayaan data dan atau informasi yang diperoleh peneliti. Menurut H.B. Sutopo (2002) bahwa "Sumber data dalam penelitian kualitatif bisa berupa orang, peristiwa dan lokasi benda, dokumen atau arsip”.

Adapun data yang diperlukan dalam penelitian ini adalah meliputi:

1. Data dan informasi tentang keadaan umum sekolah SMP Juara yang menjadi objek penelitan.

2. Data dan informasi tentang keadaan dan perkembangan pendidikan di SMP Juara, yang berkaitan dengan komponen murid, guru, sekolah, ruang kelas, kelas, keuangan pendidikan dan kelengkapan fasilitas pendidikan lainnya termasuk sarana dan prasarana.

3. Data dan informasi yang berkaitan dengan perilaku yang direpresentasikan melalui pendapat dinas pendidikan, kepala sekolah, guru, komite sekolah dan masyarakat.

M. Burhan Bungin (2007) "metode pengumpulan data kualitatif yang paling indenpenden terhadap semua metode pengumpulan data dan teknik analisis data adalah metode wawancara mendalam, observasi partisipasi, bahan dokumenter". Dalam penelitian ini untuk mendapatkan data yang valid dan reliable, maka penulis gunakan teknik pengumpulan data. Adapun teknik pengumpulan data dalam penelitian ini adalah sebagai berikut: 
1. Pengamatan (Observasi)

M. Burhan Bungin (2007) "Observasi adalah metode pengumpulan data yang digunakan untuk menghimpun data penelitian melalui pengamatan dan pengindraan”.

\section{Wawancara}

Sumber data yang penting dalam penelitian kualitatif adalah manusia dalam posisi sebagai nara sumber atau informan untuk memeperoleh informasi. Wawancara adalah bentuk komunikasi verbal yang bertujuan untuk memperoleh informasi yang diperlukan dalam penelitian.

\section{Dokumentasi}

Dokumentasi dalam penelitian ini antara lain dokumen dari sekolah yang meliputi dokumen mengenai keadaan umum sekolah, data siswa, data guru, sarana dan prasarana, kegiatankegiatan di SMP Juara Pekanbaru, serta data penunjang lainnya.

Penelitian kualitatif tidak menguji hipotesis yang dibuat sebelum penelitian. Proses analisis data dilakukan secara bersamaan dan berkelanjutan dengan proses pengumpulan data. Menurut Sugiyono (2012) “analisis data adalah proses mencari dan menyusun secara sistematis data yang diperoleh dari hasil wawancara, catatan lapangan, dan dokumentasi, dengan cara mengorganisasikan data ke dalam kategori, menjabarkan ke dalam unit-unit, melakukan sintesa, menyusun ke dalam pola, memilih mana yang penting dan yang akan dipelajari, dan membuat kesimpulan sehingga mudah difahami oleh diri sendiri maupun orang lain”.

\section{Pengumpulan Data}

Data kualitatif terutama terdiri dari katakata, bukan angka-angka. Data yang diperoleh dari hasil wawancara, observasi, maupun dokumentasi tersebut dikumpulkan menjadi satu untuk diproses lebih lanjut.

\section{Reduksi Data}

Sugiyono (2015) “Mereduksi data berarti merangkum, memilih hal-hal yang pokok, memfokuskan pada hal-hal yang penting, dicari tema, dan polanya”. Data yang diperoleh dari lapangan ditulis dalam bentuk uraian atau laporan yang terperinci.

\section{Penyajian Data}

Penyajian data atau display data merupakan penyusunan sekumpulan informasi yang diperoleh dari penelitian yang memberikan kemungkinan adanya penarikan kesimpulan dan pengambilan data.

\section{Menarik Kesimpulan atau Verifikasi \\ Data diperoleh peneliti di lapangan mulai} dilakukan penarikan kesimpulan sementara sejak penelitian dimulai, untuk itu perlu dicari pola, tema, hubungan, persamaan, hal-hal yang sering timbul dan sebagainya. Kesimpulan dibuat lebih mantap dan dapat dipertanggung jawabkan, maka perlu dilakukan verifikasi terlebih dahulu. Verifikasi merupakan kegiatan yang dilakukan kembali dengan tujuan pemantapan kesimpulan dengan cara penelusuran kembali data dengan cepat sehingga penelitian dapat mengubah kesimpulan.

Dalam Penelitian Kualilatif, harus dilakukan uji keabsahan atau validitas data. Dalam rangka memenuhi kriteria validasi terhadap temuan penelitian maka peneliti melakukan tahapantahapan validasi sebagaimana dijelaskan Sugiyono (2012),’Uji keabsahan data dalam penelitian kualitatif meliputi uji, credibility (validitas internal), transferability (validitas eksternal), dependability (reliabilitas), dan confirmability (obyektivitas).

\section{Kredibilitas}

Dalam penelitian kualitatif disebut validasi internal, merupakan salah satu ukuran tentang kebenaran data yang dilkumpulkan yang menggambarkan kecocokan konsep peneliti dengan konsep yang ada pada responden atau narasumber. Adapun tahapan yang dilakukan adalah: 
a. Triangulasi.

b. Pembicaraan dengan kolega (peer debriefing).

c. Member check.

\section{Transperabilitas}

Dalam penelitian kualitatif disebut validitas eksternal, artinya hasil penelitian dapat diterapkan atau digunakan di tempat dan dalam situasi lain yang berbeda.

\section{Dependabilitas dan Konfirmabilitas}

Dependabilitas merupakan salah satu kriteria kebenaran dalam penelitian kualitatif (sama dengan reliabilitas dalam penelitian kuantitatif). Sedangkan konfirmabilitas berkenaan dengan objektivitas hasil penelitian, dapat dilakukan dengan audit trial.

\section{HASIL DAN PEMBAHASAN}

Subfokus 1: Memahami Implementasi Kebijakan Sekolah Gratis di SMP Juara Pekanbaru.

Secara umum, implementasi berarti pelaksanaan atau penerapan. Implementasi selalu dikaitkan dengan suatu kegiatan yang dilaksanakan untuk mencapai tujuan tertentu.

Dari hasil wawancara yang sudah dilakukan dengan informan, maka dapat dideskripsikan pemahaman tentang tujuan dan peran serta tenaga pendidik dan kependidikan dalam implementasi kebijakan sekolah gratis di SMP Juara sebagai berikut:

a. Pemahaman terhadap tujuan yang melatarbelakangi implementasi kebijakan sekolah gratis.

Tenaga pendidik dan kependidikan yang terlibat dalam implementasi sekolah gratis di SMP Juara sudah memahami dengan baik tentang tujuan yang melatarbelakangi implementasi kebijakan sekolah gratis ini. Dari hasil observasi dan wawancara yang sudah dilakukan, secara keseluruhan menyatakan bahwa tujuan utama sekolah gratis ini adalah untuk membantu siswasiswa yang kurang mampu agar bisa mendapatkan pendidikan yang layak dan berkualitas. Dan tujuan implementasi kebijakan sekolah gratis tersebut sudah terealisasikan dengan baik di SMP Juara.

b. Pemahaman tentang peran serta masingmasing tenaga pendidik dan kependidikan yang terlibat dalam pelaksanaan implementasi kebijakan sekolah gratis.

Seluruh tenaga pendidik dan kependidikan sudah memahami bagaimana peran mereka masing-masing dalam implementasi kebijakan sekolah gratis di SMP juara. Dan dari hasil wawancara dan observasi yang dilaksanakan, dapat disimpulkan bahwa sebagai pembuat kebijakan yaitu Yayasan Rumah Zakat dan partisipannya yaitu seluruh tenaga pendidik dan kependidikan yang ada di SMP Juara sudah melaksanakan peran dan tanggung jawab mereka masing-masing dengan baik.

\section{A. Subfokus 2: $\quad$ Sasaran, Persyaratan dan Anggaran dalam Penerapan Implementasi Kebijakan Sekolah Gratis yang Dilaksanakan.}

Dalam pandangan Edwards III, implementasi kebijakan dipengaruhi oleh empat variabel, yakni: (a) Komunikasi; (b) Sumberdaya; (c) Disposisi; (d) Struktur birokrasi

1) Sasaran

Yang menjadi Sasaran kebijakan sekolah gratis SMP Juara Pekanbaru yaitu memberikan pendidikan kepada siswa-siswa yang kurang mampu dari segi ekonomi untuk memperoleh pendidikan yang berkualitas sehingga diharapkan bisa melahirkan lulusan yang berpengetahuan, berpestasi, dan memiliki skill sehingga bisa bersaing melanjutkan ke sekolah SMA, MA, dan SMK negeri favorit. Akan tetapi SMP Juara Pekanbaru kurang berhasil mencapai sasaran, karena jumlah siswa lulusan yang diterima di sekolah negeri lebih sedikit dari pada sekolah swasta.

2) Persyaratan

Adapun yang menjadi persyaratan penerimaan siswa di SMP Juara antara lain: 
1. Seleksi administrasi yaitu surat pernyataan keluarga kurang mampu dari RT/RW/ Kelurahan/Kecamatan yang kemudian dilanjutkan dengan survey langsung yang dilakukan oleh pihak sekolah ke rumah calon peserta didik.

2. Tes Psikologi, untuk memahami tingkat kemampuan dan bakat peserta didik.

3. Tes Akademik, untuk melihat kemampuan dasar akademik peserta didik.

4. Wawancara, wawancara dilakukan kepada peserta didik dan orang tuanya.

Dalam wawancara dengan staf tata usaha, persyaratan siswa baru dilihat juga dari segi usia, maksudnya disini ada batasan umur untuk yang diterima di SMP Juara adalah maksimal 1 tahun sebelum angkatan yang diterima misal jika angkatan tahun ini untuk kelahiran 2000, maka kita beri dispensasi untuk kelahiran tahun 1999 untuk diterima di SMP Juara. Untuk persyaratan ini tidak dicantumkan dalam formulir pendaftaran yang mana di dalam formulir tersebut terdapat persyaratan-persyaratan yang harus dilengkapi siswa baru ketika mendaftar di SMP Juara.

\section{3) Anggaran}

Sesuai dengan kebijakan Rumah Zakat, bahwa semua sumber pembiayaan pendidikan, sarana dan prasarana, serta biaya operasional seperti buku pegangan siswa, seragam sekolah dibiayai oleh yayasan dan donatur. Serta ditambah dengan Bantuan Operasional Sekolah (BOS) dari pemerintah.

Besarnya anggaran tiap tahunnya 2013 yaitu Rp.260.878.913, anggaran yang digunakan yaitu Rp.255.677.790, dengan persentase penggunaan anggaran 98\%. Tahun 2014 yaitu Rp.244.671.000, anggaran yang digunakan yaitu Rp.217.731.300, dengan persentase penggunaan anggaran 89\%. Tahun 2015 yaitu Rp.267.413.200, anggaran yang digunakan yaitu Rp.259.344.100, dengan persentase penggunaan anggaran 97\%. Besarnya jumlah anggaran tiap tahunnya bervariasi tergantung jumlah yang dibutuhkan dan penambahan jumlah siswa.

\section{B. Subfokus 3: $\quad$ F a k t o r - f a k t or Pendukung Implementasi Kebijakan Sekolah Gratis di SMP Juara Kota Pekanbaru.}

Berdasarkan hasil wawancara dengan partisipan, hasil observasi dan dokumentasi dilapangan yang telah dilakukan, maka ditemukan beberapa faktor pendukung pelaksanaan implementasi kebijkan sekolah gratis di SMP Juara ini.

Dari informasi yang diperoleh tersebut, akan dipaparkan sesuai dengan empat faktor penentu keefektifan kebijakan menurut Edward III sebagaimana yang sudah penulis sampaikan dibagian sebelumnya, yaitu:

1. Komunikasi

Dari hasil wawancara, informasi yang diperoleh dari partisipan adalah bahwa kebijakan sekolah gratis di SMP Juara telah diimplementasikan sejak tahun 2012 yang ditujukan untuk anak kurang mampu, dan kebijakan sekolah gratis ini sudah terlaksana dengan cukup baik. Ditambah lagi dengan adanya dukungan pemerintah kota Pekanbaru kepada SMP Juara ini, seperti dengan memberikan izin operasional sekolah kepada SMP Juara dan juga pemberian dana BOS.

\section{Sumber Daya}

Meskipun SMP Juara ini adalah sekolah swasta milik yayasan, namun pemerintah dan masyarakat menyambut baik keberadaan sekolah gratis ini. Sekolah gratis ini merupakan program yayasan Rumah Zakat untuk membantu siswa yang kurang mampu secara ekonomi untuk melanjutkan pendidikan mereka. Operasional sekolah tentu saja tidak lepas dari peran serta tenaga pendidik dan kependidikan yang terlibat langsung dalam pelaksanaanya dimana tenaga pendidik dan kependidikan yang ada di SMP juara ini sudah memiliki kualifikasi pendidikan yang sesuai.

\section{Disposisi}

Pada dimensi ini dapat diukur dari prestasi siswa sejak implementasi kebijakan sekolah 
gratis ini dilaksanakan. Informasi tersebut dapat kita peroleh salah satunya dari hasil Ujian Nasional siswa yang merupakan siswa angkatan pertama yang menamatkan pendidikan di SMP juara dan hasilnya bisa dikatakan baik.

\section{Struktur Birokrasi}

Struktur atau prosedur birokrasi yang dilaksanakan di SMP juara bisa dikatakan kompleks, hal tersebut didukung dari hasil wawancara dan informasi yang diperoleh seperti dalam pelaksanaan penerimaan siswa baru. Siswa yang mendaftar di SMP juara ini harus mengikuti serangkaian tes untuk membuktikan apakah mereka layak menerima pendidikan gratis di SMP Juara ini. Disamping itu, komitmen orangtua pun juga diminta untuk bisa ikut serta dalam proses pendidikan anak mereka di SMP juara ini yaitu dengan berkewajiban mengikuti kegiatan konseling dan parenting yang diadakan oleh pihak sekolah.

\section{Subfokus 4: Kendala-kendala yang Muncul dalam Implementasi Kebijakan Sekolah Gratis.}

Kendala yang ditemui dalam implementasi sekolah gratis di SMP Juara ini yaitu berdasarkan hasil wawancara dengan partisipan, hasil observasi dan dokumentasi dilapangan. Selanjutnya akan disimpulkan berdasarkan empat faktor penentu keefektifan kebijakan menurut Edward III, yaitu :

\section{Komunikasi}

Dari informasi yang berhasil dihimpun melalui wawancara, kendala yang muncul datang dari siswa, dimana sebagian dari siswa tersebut masih belum memahami pentingnya pendidikan sehingga meskipun diberikan pendidikan gratis, mereka masih saja enggan mengikuti pendidikan tersebut. Sejalan dengan itu, masih ada orang tua yang kurang peduli terhadap pendidikan anaknya karena mereka menganggap mencari uang itu lebih penting dari pada sekolah. Kemudian kendala lainnya yaitu dari segi kelengkapan fasilitas yang ada disekolah seperti belum adanya labor IPA, aula dan beberapa fasilitas lainnya untuk menunjang aktifitas belajar mengajar.

2. Sumberdaya

Dimensi kedua ini menjadi salah satu penentu kesuksesan implementasi kebijakan sekolah gratis di SMP juara ini. Namun di SMP juara ini ditemui kendala dari SDM atau tenaga pendidik dan kependidikannya yang kurang mencukupi sehingga dengan kurangnya tenaga pengajar maka ada sebagian guru yang mengajar lebih dari satu mata pelajaran selain dari bidang yang diampunya.

\section{Disposisi}

Jika diukur dari segi prestasi siswanya, maka implementasi kebijakan sekolah gratis di SMP Juara sudah bisa dikatakan baik, hal tersebut bisa kita lihat dari prestasi-prestasi yang telah diperoleh siswa SMP Juara diberbagai bidang perlombaan selama hampir 4 tahun sekolah ini didirikan. Akan tetapi prestasi yang diperoleh sebagian besarnya adalah prestasi non akademik, sedangkan untuk prestasi akademiknya bisa dikatakan belum terlalu baik. Informasi tersebut bisa kita lihat pada grafik berikut.

\section{Struktur Birokrasi}

Dari informasi yang berhasil dihimpun melalui wawancara dan observasi dilapangan, SMP juara menerima anggaran untuk operasionalnya tentunya dari Yayasan Rumah Zakat. Namun ada juga alokasi dana bantuan dari pemerintah berupa dana BOS. Dari informasi yang diperoleh, alokasi dana BOS ini sering mengalami keterlambatan karena birokrasi yang panjang dalam pencairan dana BOS tersebut.

\section{Subfokus 5 : Mengatasi Kendala- kendala dalam Implementasi Kebijakan Sekolah Gratis.}

Untuk pemecahan masalah dari segi keterbatasan sumberdaya manusia, yang mana masih ada beberapa tenaga pendidik yang 
diperbantukan mengajar mata pelajaran lain selain ilmu terapannya, maka pihak sekolah meminimalisirnya dengan cara merekrut tenaga honorer yaitu 1 orang guru dan 1 orang staf TU. Meskipun begitu, dengan ditambahnya tenaga pendidik dan kependidikan belum sepenuhnya mampu mengatasi kendala yang dihadapi karena masih ada guru yang harus merangkap mengajar mata pelajaran lain selain ilmu terapannya, maka dari itu sebaiknya dari pihak yayasan melalui penyampaian dari pihak sekolah sebaiknya menambah tenaga pendidik agar proses pembelajaran bisa terlaksana dengan lebih baik dan sebagaimana mestinya, yang mana guru tersebut masing-masing fokus untuk mengajar dibidang ilmu terapannya.

Selanjutnya untuk pemecahan masalah bagi anak yang bermasalah misalnya tidak mau sekolah meskipun segala fasilitas sudah gratis, pihak sekolah sudah memiliki program pembinaan/konseling yang diberikan kepada siswa dan orang tua namun, sebagian dari mereka masih kurang komitmennya untuk mengikuti kegiatan tersebut. Pihak sekolah seharusnya lebih selektif lagi ketika melakukan penerimaan peserta didik baru yang tiap tahunnya pendaftar di SMP Juara ini semakin meningkat, sehingga penerima manfaat yang dalam hal ini adalah siswa dan orang tua bisa memahami pentingnya pendidikan dan bisa mengikuti kegiatan yang menjadi program sekolah gratis ini dengan baik.

Kemudian pemecahan keterbatasan lahan dan belum adanya fasilitas ruangan seperti labor IPA dan aula, pihak sekolah sudah melakukan upaya dengan memanfaatkan perpustakaan dengan memberikan sekat sebagai pembatas untuk dijadikan sebagai labor IPA, kemudian untuk sementara, kegiatan-kegiatan siswa dan parenting terkadang dilaksanakan di musholla ataupun ruang kelas karena belum adanya aula.

Sedangkan untuk keterlambatan pencairan dana BOS dari pemerintah, pihak sekolah memanfaatkan dana dari yayasan atau dari donatur-donatur yang memberikan bantuan kepada sekolah SMP Juara.

\section{SIMPULAN DAN SARAN}

Implementasi Kebijakan sekolah gratis yang dilaksanakan oleh Yayasan Rumah Zakat secara konsep sudah benar, artinya kebijakan tersebut tidak mengandung permasalahan dalam formulasinya. Setelah melakukan penelitian dan analisis data dapat disimpulkan, sebagai berikut:

1. Realisasi implementasi kebijakan sekolah gratis di SMP juara sudah memenuhi tujuan utamanya yakni menghadirkan sekolah gratis dan berkualitas yang bertujuan untuk membantu pendidikan siswa yang kurang mampu.

2. Siswa yang berasal dari keluarga tidak mampu yang merupakan sasaran (input) implementasi sekolah gratis ini, dan yang menjadi outputnya yaitu melahirkan lulusan yang juara maksudnya mampu bersaing untuk masuk disekolah negeri favorit, akan tetapi untuk lulusan pertama sebagian besar siswa melanjutkan pendidikan mereka kesekolah-sekolah swasta berbayar.

3. Dukungan utama yang diperoleh SMP juara tentunya dari Yayasan Rumah Zakat dan dari para donatur-donatur. Kemudian dukungannyajuga diperoleh dari Pemerintah Kota Pekanbaru yang telah memberikan izin operasinal sekolah serta bantuan operasional sekolah.

4. Kendala-kendala dalam implementasi sekolah gratis antara lain: (1) keterbatasan lahan sekolah serta fasilitas-fasilitas ruangan pendukung yang belum dimiliki seperti belum adanya aula dan labor IPA; (2) adanya keterlambatan pencairan dana BOS; (3) kurangnya tenaga pengajar yang ada di SMP Juara sehingga masih ada beberapa guru yang mengajar selain bidang keahliannya; (4) masih ada siswa yang malas sekolah meskipun sudah diberikan fasilitas gratis karena kebanyakan dari mereka bekerja membantu orang tuanya diluar jam sekolah; (5) kurangnya komitmen orang tua dalam memotivasi pendidikan anaknya, hal ini dilihat dari kurangnya komitmen orang tua dalam mengikuti kegiatan konseling dan parenting 
yang sudah menjadi komitmen awal bagi orang tua yang anaknya bersekolah di SMP Juara.

5. Untuk mengatasi kendala-kendala yang dihadapi: (1) solusi keterbatasan tenaga pengajar yang dilakukan pihak sekolah adalah dengan memberdayakan guru untuk mengajar mata pelajaran lain selain bidang yang diampunya; (2) keterbatasan lahan sekolah sudah dilaporkan kepada pihak yayasan agar diupayakannya pembelian lahan untuk perluasan sekolah; (3) belum lengkapnya fasilitas ruang yang dibutuhkan sehingga dilakukan upaya dengan memanfaatkan fasilitas yang ada, misalnya menjadikan memberi sekat diruang perpustakaan yang sebagian ruangannya dijadikan labor IPA.

Berdasarkan hasil temuan dan pemaparan kesimpulan di atas, maka dapat direkomendasikan hal-hal berikut:

1. Agar implementasi kebijakan sekolah gratis ini lebih baik dan tepat sasaran, maka perlu optimalisasi untuk faktor internal dan eksternal terutama komunikasi, dengan melaksanakan sosialisasi secara optimal, faktor sumberdaya, diisi oleh mereka yang kompeten, faktor sikap pelaksana dan struktur birokrasi perlu dibangun kesadaran akan tugas dan tanggung jawab masingmasing.

2. Kebijakan sekolah gratis merupakan kegiatan yang positif dan perlu dilanjutkan, karena kebijakan sekolah gratis meringankan beban orang tua dalam menyekolahkan anaknya, dan dapat mengurangi angka putus sekolah.

3. Perhatian dan keterlibatan pemerintah perlu ditingkatkan terhadap pelaksanaan kebijakan sekolah graris yang diprakarsai oleh Yayasan Rumah Zakat ini karena secara tidak langsung, keberadaan sekolah gratis ini sangat membantu pemerintah dalam mensukseskan permasalahan pendidikan wajib belajar 9 tahun yang mana masih tingginya angka putus sekolah karena keterbatasan biaya.

4. Segala kendala-kendala yang ada dalam implementasi kebijakan sekolah gratis ini perlu ditanggulangi dengan cepat supaya semua kegiatan yang ada disekolah dapat terlaksana dengan baik dan sebagaimana mestinya.

\section{DAFTAR PUSTAKA}

Bugin, M. Burhan. 2007. Penelitian Kualitatif. Prenada Media: Jakarta.

Dyah Puspitoningrum, Ilhami. 2009. Implementasi kebijakan Pendidikan Gratis di SMP Negeri 1 Polokarto Tahun Ajaran 2008/2009. Universitas Sebelas Maret.

Fattah, Nanang. 2012. Analisis Kebijakan Pendidikan. Remaja Rosdakarya: Bandung.

Fattah, Nanang. 2002. Ekonomi dan Pembiayaan Pendidikan. Remaja Rosdakarya: Bandung.

Hamalik, Oemar. 2010. Proses Belajar Mengajar. Bumi Aksara: Jakarta.

Hasbullah. 2015. Kebijakan Pendidikan. Rajawali Pers: Jakarta.

Jhon W. Creswell. 2011. Penelitian Kualitatif Dalam Bidang Pendidikan. UMRI Press: Pekanbaru.

Kardianarizant, Eri. Sasaran Kebijakan Publik. http://wordpress.com/2012/09/02

Muwarti, Nanik. 2010. Implementasi Kebijakan Restrukturisasi Organisasi Perangkat Daerah. FISI UI.

Nugroho, Riant. 2008. Public Policy. PT Elex Media Komputindo: Jakarta.

Purnamasari, Eci. 2015. Implementasi Kebijkan Sekolah Gratis SMA Negeri Pintar Kabupaten Kuantan Singingi Provinsi Riau. Universitas Riau.

Rasul, Sjahruddin dkk. 2000. Mengenal Proses Kebijakkan Publik. BPKP: Jakarta.

Sugiyono. 2012. Metode Penelitian Pendidikan. Alfabeta: Bandung. 
Sugiyono. 2015. Metode Penelitian dan Pengembangan. Alfabeta: Bandung.

Supriyatno. 2010. Analisis Implementasi

Kebijakan Sekolah Gratis di SDN

Cilengsi dan Cinyosog Bogor. Fisip UI

Undang-Undang Dasar Republik Indonesia 1945.
Undang-Undang Dasar Republik Indonesia 1945 Pasal 31 ayat 1 dan 2 .

Undang-Undang Nomor 20 Tahun 2003 Tentang Sistem Pendidikan Nasional. 